ATTHULAB:

Islamic Religion Teaching \& Learning Journal

Volume 4 Nomor 2 Tahun 2019

http://journal.uinsgd.ac.id./index.php/atthulab/

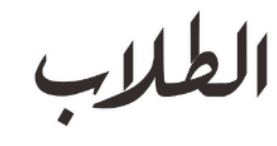

\title{
Sikap sosial siswa dalam kegiatan infaq
}

\author{
Ari Irawan \\ Sekolah Menengah Pertama Islam Terpadu Anni'mah Al Karimah \\ Jalan Sampora Sekeawi Kab. Bandung Jawa Barat 40227 Indonesia \\ Email: ariekspirawan696@gmail.com
}

\begin{abstract}
This study aims to identify: 1) Student activities in the implementation of information at SMAN 1 Bojongsoang; 2) Social attitudes of students in the high school; 3) Influence of student activities in the implementation of information on the social attitudes of students in the high school. This research was conducted using a quantitative approach. To obtain data on the influence of student activity in infaq and social attitudes, the author uses questionnaire techniques, observation and interviews. The sample in this study were 40 people. After the data is collected, then it is analyzed statistically using the steps of data normality test, linear regression and correlation. Student activities in infaq activities are very high. This is based on an average value of 4.27 from 5.00. Students' social attitudes are high. This is based on an average value of 4.16 from 5.00. While the correlation coefficient number 0.11 is categorized as very low because it is at the interval of $0.00-0.20$. Meanwhile the degree of variable $X$ to the variable $Y$ is $1.21 \%$. Keywords:

student activity; infaq; social attitude
\end{abstract}

\begin{abstract}
Abstrak: Penelitian ini bertujuan untuk mengidentifikasi: 1) Aktivitas siswa dalam pelaksanaan infaq di SMAN 1 Bojongsoang; 2) Sikap sosial siswa di SMAN tersebut; 3) Pengaruh aktivitas siswa dalam pelaksanaan infaq terhadap sikap sosial siswa di SMAN tersebut. Penelitian ini dilakukan dengan menggunakan pendekatan kuantitatif. Untuk memperoleh data mengenai pengaruh aktivitas siswa dalam kegiatan infaq dan sikap sosial, penulis menggunakan teknik angket, observasi dan wawancara. Sampel dalam penelitian ini sebanyak 40 orang. Setelah data terkumpul, kemudian dianalisis secara statistik dengan menggunakan langkah-langkah uji normalitas data, regresi linier dan korelasi. Aktivitas siswa dalam kegiatan infaq tergolong sangat tinggi. Hal ini didasarkan nilai rata-rata sebesar 4,27. Sikap sosial siswa tergolong tinggi. Hal ini didasarkan pada nilai rata-rata sebesar 4,16. Sedangkan Angka koefisien korelasi 0,11 termasuk kategori sangat rendah karena berada pada interval 0,00 - 0,20. Sementara itu derajat pengatuh Variabel X terhadap Variabel Y diketahui 1,21\%.

Kata kunci:

aktivitas siswa; infaq; sikap sosial
\end{abstract}

DOI: http://dx.doi.org/10.15575/ath.v4i2.4724

Received: 06, 2019. Accepted: 10, 2019. Published: 11, 2019

\section{PENDAHULUAN}

Siswa di SMAN 1 Bojongsoang memiliki sikap sosial yang kurang tertanam dan teraplikasikan. Pada zaman sekarang dan rata-rata pendidikan mencetak hasil yang cerdas secara kognitif saja, padahal sangatlah penting mencetak peserta didik yang cerdas secara lahiriyah dan bathiniyah. Kecerdasan sosial humanistik, kecerdasan spiritual dan lain-lain. Kegiatan infaq merupakan serangkaian kegiatan dan program unggulan yang dilakukan di SMAN 1 Bojongsoang yang bertujuan untuk membentuk jiwa peduli sosial pada peserta didik di SMAN 1 Bojongsoang baik pada saat mereka sedang menuntut ilmu di sekolah maupun dalam kehidupan sehari-hari. Dalam kegiatan infaq ditanamkan aspek kepekaan terhadap orang lain, peduli sosial terutama 
pada orang yang membutuhkan. Kegiatan infaq ini dalam implementasinya dikoordinir oleh pihak DKM Darul Ilmi SMAN 1 Bojongsoang yaitu oleh Dadang, S.Pd selaku ketua DKM dan dibantu oleh guru-guru SMAN 1 Bojongsoang yang bertugas sebagai guru piket pada hari itu serta sebagian siswa.

Selain itu Faisal bin Ali Al-Ba'dani (2009:130) menjelaskan bahwa syariat Islam bertujuan untuk mewujudkan kelapangan hati seseorang dan keridhaan seseorang yang mengeluarkan dan menerima infaq, terciptanya masyarakat yang dinamis, gemar tolong menolong sesama manusia dan menjadi perekat ukhuwah Islamiyah. Hal tersebut menekankan bahwa Islam adalah agama yang kaffah dan mempunyai satu tujuan, satu pemikiran, satu landasan dan satu kewajiban yang harus ditegakkan.

Wahyudi Siswanto (2010:73-82) menjelaskan bahwa proses penanaman karakter kepedulian sosial ini dimulai sejak sedini mungkin dengan menggunakan berbagai metode seperti keteladanan, perbuatan, dengan nasihat, permainan, cerita, pembiasaan tingkah laku, pembiasaan perkataan, perhatian, pemantauan dan lain-lain. Dengan demikian, berdasarkan latar belakang masalah di atas, peneliti merasakan sangat penting untuk melakukan penelitian penanaman sikap sosial di SMAN 1 Bojongsoang yang sifat ini masih langka dan jarang pada anak usia remaja. Untuk mengasah kepekaan hati terhadap lingkungan sekitar, memberi dengan hati ikhlas, rela empati siswa setingkat SMA dengan menyisihkan sebagian uang jajannya bagi orang lain yang membutuhkan, yang biasanya remaja sibuk dengan masa remajanya dan kurang peka terhadap kehidupan sosial. Maka peneliti termotivasi dengan rasa ingin tahu yang tinggi untuk melakukan penelitian lebih lanjut.

Berdasarkan latar belakang yang telah dipaparkan sebelumnya, permasalahannya dapat dirumuskan sebagai berikut: (1) Bagaimana aktivitas siswa dalam pelaksanaan infaq di SMAN 1 Bojongsoang; (2) Bagaimana sikap sosial siswa di SMAN tersebut; (3) Sejauh mana pengaruh aktivitas siswa dalam pelaksanaan infaq terhadap sikap sosial siswa di SMAN 1 tersebut.

Berdasarkan perumusan masalah di atas, tujuan penelitian ini adalah untuk mengidentifikasi: aktivitas siswa dalam pelaksanaan infaq di SMAN 1 Bojongsoang, sikap sosial siswa di SMAN tersebut, dan pengaruh aktivitas siswa dalam pelaksanaan infaq terhadap sikap sosial siswa di SMAN tersebut. Secara skematis, kerangka pemikiran ini dapat digambarkan pada bagan 1. sebagai berikut: 


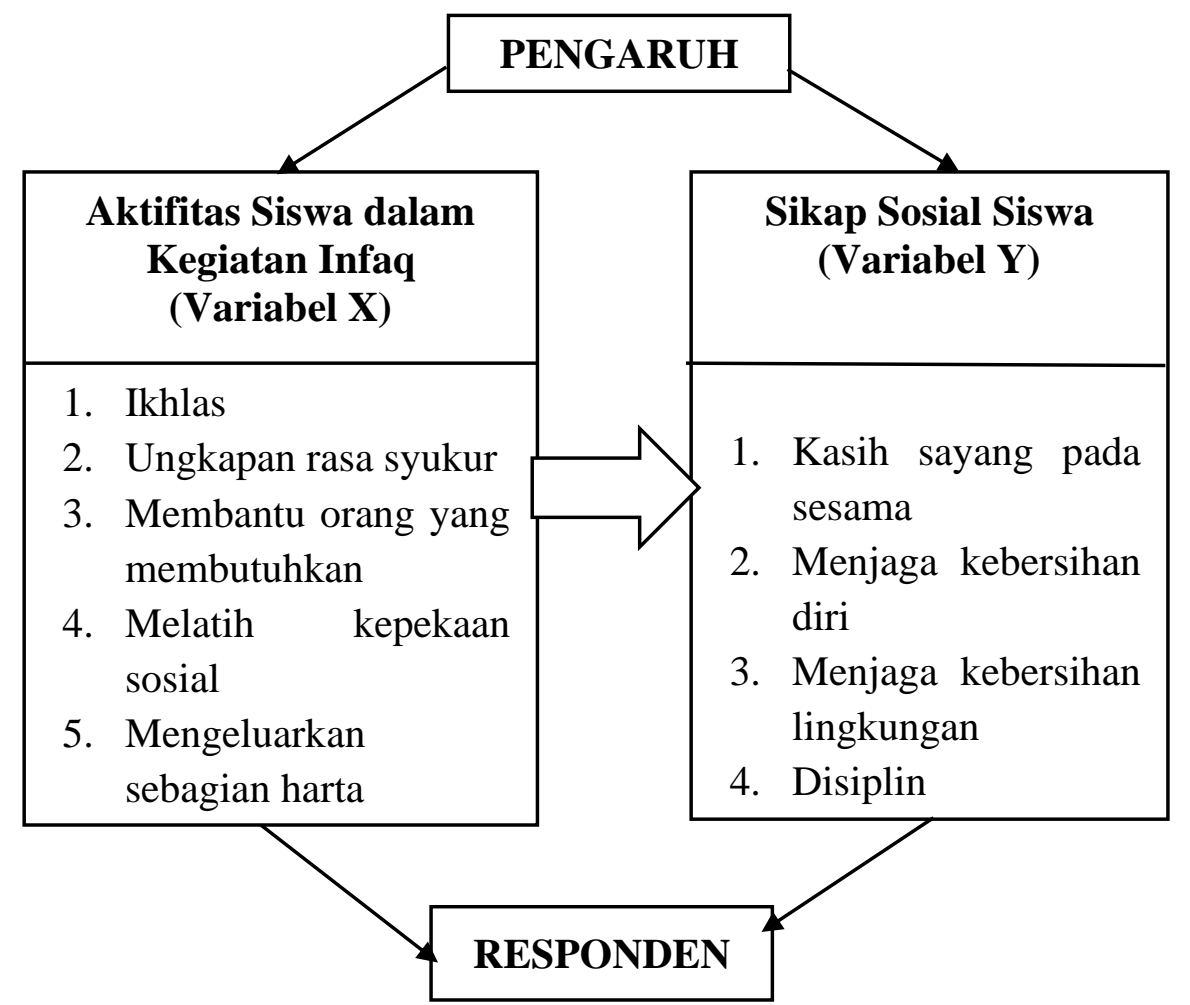

Bagan 1. Pengaruh Aktifitas Siswa dalam Kegiatan Infaq terhadap Sikap Sosial Mereka

Dalam penelitian ini dapat diasumsikan hipotesisnya bahwa antusiasme para siswa terhadap kegiatan infaq akan menumbuhkan sikap kepedulian sosial mereka. Dengan demikian, maka penelitian ini dapat diambil hipotesis sebagai berikut: "Semakin tinggi antusiasme siswa terhadap aktivitas kegiatan infaq, semakin tinggi pula sikap sosial siswa tersebut. Sebaliknya jika semakin rendah antusiasme siswa terhadap aktifitas siswa dalam kegiatan infaq, maka akan semakin rendah pula sikap sosial siswa tersebut"

Untuk mengetahui kebenaran hipotesis tersebut maka digunakan rumus $t_{\text {hitung }}$ dan $t$ tabel yaitu jika $t$ hitung lebih besar dari $t$ tabel maka hipotesis nol (Ho) ditolak berarti ada hubungan antara variabel $\mathrm{X}$ dan variabel $\mathrm{Y}$. Jika $\mathrm{t}$ hitung lebih kecil dari $\mathrm{t}$ tabel maka hipotesis nol (Ha) diterima berarti tidak ada hubungan antara variabel X dan $\mathrm{Y}$.

Adapun hasil penelitian terdahulu diantaranya: musfirotun. 2013. Hubungan Keaktifan Mengikuti Kegiatan Pengajian Malam Jum'at Dengan Sikap Sosial Ibu Rumah Tangga di Karangrejo Rt003 Rw 003 Kelurahan Kecandran Kecamatan Sidomukti Kota Salatiga Tahun 2013. Skripsi Jurusan Tarbiyah Program Studi Pendidikan Agama Islam Sekolah Tinggi Agama Islam Negeri. Penelitian ini merupakan upaya untuk mengetahui pentingnya berkumpul, dalam hal ini pengajian malam jum'at untuk menumbuhkan sikap sosial yang dimiliki oleh Ibu rumah tangga yang ada di Karangrejo Rt 003 Rw 003 Kelurahan Kecandran Kecamatan Sidomukti Kota Salatiga. Meskipun penelitian di atas merupakan studi deskriptif dan korelasi mengenai implementasi dan keaktifan mengikuti kegiatan pengajian malam jum'at dengan sikap sosial ibu rumah tangga, namun penelitian ini lebih berfokus pada kegiatan infaq pengaruhnya terhadap kepedulian siswa di SMAN 1 Bojongsoang.

Setiawan, Khafidz. 2013. Hubungan Keaktifan Salat Berjamaah Dengan Kedisiplinan Belajar Siswa Kelas VIII MTs Assa"id Blado Kecamatan Blado Kabupaten Batang Tahun 2013. Skripsi. Jurusan Tarbiyah. Program Studi Pendidikan Agama Islam. Sekolah Tinggi 
Agama Islam Negeri Salatiga. Penelitian ini merupakan upaya untuk mengetahui keaktifan salat berjamaah siswa kelas VIII MTs Assa'id Blado Kecamatan Blado Kabupaten Batang tahun 2013, dan untuk mengetahui kedisiplinan belajar siswa kelas VIII MTs Assa'id Blado Kecamatan Blado Kabupaten Batang tahun 2013, serta untuk mengetahui hubungan keaktifan salat berjamaah dengan kedisiplinan belajar siswa kelas VIII MTs Assa'id Blado Kecamatan Blado Kabupaten Batang tahun 2013. Meskipun penelitian di atas merupakan studi deskriptif dan korelasi mengenai implementasi dan keaktifan salat berjamaah dengan kedisiplinan belajar siswa kelas VIII MTs Assa"id Blado, namun penelitian ini lebih berfokus pada kegiatan infaq pengaruhnya terhadap kepedulian siswa di SMAN 1 Bojongsoang.

Lukman. 2013. Implementasi Ajaran Tarekat Qodariyah Wa Naksabandiyah terhadap Perubahan Perilaku Sosial Jamaah Studi Kasus Desa Doplang Kecamatan Bawen Kabupaten Semarang Tahun 2013. Skripsi. Jurusan Tarbiyah. Program Studi Pendidikan Agama Islam. Sekolah Tinggi Agama Islam Negeri Salatiga. Tarekat adalah sebuah jalan sebagai sarana mendekatkan diri kepada sang pencipta Allah SWT untuk mencapai sebuah makrifatullah jalan yang menuju ke Allah. Sebuah sarana yang dilakukan melalui dzikir-dzikir agar hati menjadi tenang dan khusuk hanya menginat sang pencipta. Meskipun penelitian di atas merupakan studi deskriptif dan korelasi mengenai implementasi ajaran tarekat qodariyah wa naksabandiyah terhadap perubahan perilaku sosial jamaah studi kasus desa Doplang kecamatan Bawen kabupaten Semarang, namun penelitian ini lebih berfokus pada kegiatan infaq pengaruhnya terhadap kepedulian siswa di SMAN 1 Bojongsoang.

\section{METODE PENELITIAN}

Penelitian ini dilakukan dengan menggunakan pendekatan kuantitatif. Adapun yang dimaksud dengan pendekatan kuantitatif adalah jenis data yang dapat diukur atau dihitung secara langsung, yang berupa informasi atau penjelasan yang dinyatakan dalam bilangan atau bentuk angka (Sugiyono, 2010:15). Dalam penelitian ini secara umum peneliti menggunakan metode deskriptif korelatif. Adapun metode deskriptif korelatif di sini yaitu untuk mendeskrifsikan atau menggambarkan realitas aktivitas siswa dalam kegiatan infaq terhadap sikap sosial mereka.

Dalam penelitian ini ada dua jenis data yaitu data kualitatif dan data kuantitatif. Data kuantitatif berupa angka yang dapat diolah dengan statistika dan untuk memperoleh data penulis menggunakan teknik pengumpulan data berupa angket yaitu dengan cara menyebaran angket kepada sejumlah responden yang telah ditetapkan sebagai objek penelitian. Sedangkan data kualitatif sebaliknya bukan berupa angka dan dalam penelitian ini penulis mengunakan teknik pengumpulan data berupa observasi, wawancara dan studi kepustakaan. Sumber penelitian ini, bersumber pada: sumber primer, sumber lapangan dan sumber sekunder.

Secara garis besar untuk memperoleh data yang diperlukan dalam penelitan ini penulis menggunakan teknik-teknik pengumpulan data yang meliputi: angket, observasi, studi pustaka dan wawancara.

Setelah data kuantitatif terkumpul yaitu angket, observasi, studi pustaka dan wawancara dengan lengkap maka akan dianalisis dengan menggunakan pendekatan statistika. Pengolahannya meliputi langkah-langkah: analisis parisal adalah analisis yang digunakan untuk menganalisis dua variable (Variable $X$ dan Variable $Y$ ), dan analisis korelasi digunakan untuk menghitung data atau mengetahui hubungan antara Variabel $\mathrm{X}$ dengan Variabel $\mathrm{Y}$. 
Penelitian ini bertempat di SMA Negeri 1 Bojongsoang yang berlokasi di Jalan Sapan Gudang RT 01 RW 03 No. 55 Desa Tegalluar Kecamatan Bojongsoang Kabupaten Bandung Kode Pos 40297 Tlp. (022) 70485448 dan difokuskan kepada siswa Kelas XI. Pemilihan lokasi ini berdasarkan atas pertimbangan peneliti, mengingat bahwa di sinilah peneliti menemukan permasalahan. Adapun waktu penelitian terhitung mulai dari bulan Februari sampai dengan bulan April.

\section{HASIL PENELITIAN DAN PEMBAHASAN}

Aktivitas dalam Kamus Besar Bahasa Indonesia adalah keaktifan, kegiatan-kegiatan, kesibukan atau salah satu kegiatan kerja yang dilaksanakan tiap bagian dalam tiap suatu organisasi atau lembaga (Dep. Pendidikan dan Kebudayaan, 2005: 23). Dalam kehidupan sehari-hari banyak sekali aktivitas, kegiatan, atau kesibukan yang dilakukan manusia, baik kegiatan tersebut bermakna bagi dirinya ataupun sebaliknya, bermakna atau tidaknya tergantung pada kebutuhan yang dianut individu yang bersangkutan. (Samuel, 1982: 52), mengatakan bahwa aktivitas tidak hanya sekedar kegiatan, tetapi aktivitas dipandang sebagai usaha mencapai atau memenuhi kebutuhan. Salah satu kebutuhan manusia adalah menuntut ilmu untuk menjadi orang yang pandai dan sukses. Untuk memenuhi kebutuhan tersebut, manusia belajar dengan cara bersekolah atau mengikuti majlis atau tempat-tempat ilmu, membaca buku, berdiskusi dan melakukan kegiatan lainnya. Misalnya, seseorang yang ingin mendalami ilmu agama dan hubungan interaksi masyarakat yang Islami, maka ia harus melakukan aktivitas yang dapat mewujudkan keinginan tersebut. Aktivitas yang dilakukan dengan membaca buku-buku agama, mengikuti pengajian-pengajian, mengkaji norma-norma ajaran Islam tentang hubungan sesama manusia, dan yang paling penting adalah dapat mengaplikasikan ilmu yang telah didapatkan ke dalam kehidupan nyata.

Nursyamsudin (2009) menjelaskan shadaqah wajib (zakat harta dan zakat fitrah) maupun shadaqoh sunnah (shadaqoh, derma) termasuk dalam cakupan infaq fi sabilillah (menafkahkan atau membelanjakan harta dijalan Allah). Eko Suswanto (2018) menjelaskan zakat secara syariah terdapat beberapa definisi zakat yang dikemukakan oleh ulama mazhab, diantaranya adalah sebagai berikut: Ulama mazhab Maliki mendefinisikan zakat adalah mengeluarkan bagian tertentu dari harta tertentu yang telah mencapai satu nisab bagi orang yang berhak menerimanya, dengan ketentuan harta itu milik sempurna, telah haul. Ulama Mazhab Hanafi mendefinisikan zakat adalah pemilikan bagian tertentu yang dimiliki seseorang berdasarkan ketetapan Allah SWT.Ulama Mazhab Syafi'i mendefinisikan zakat adalah sesuatu yang dikeluarkan dari harta atau jiwa dengan cara tertentu.Ulama Mazhab Hambali mendefinisikan zakat adalah hak wajib pada harta tertentu pada waktu yang tertentu pula. Pembagian infaq dibagi menjadi dua bagian yaitu ada yang bersifat wajib dan ada yang bersifat anjuran. Infaq yang bersifat wajib seperti tanggung jawab seorang suami menafkahi keluarganya yaitu anak dan istrinya (keluarga) seperti memberi tempat tinggal, memberi makan, dan pemenuhan kebutuhan hidup kesehariannya. Adapun infaq yang bersifat anjuran yaitu mengeluarkan sebagian harta yang kita miliki terhadap orang yang membutuhkan dan bersifat soaial, seperti menginfaqkan harta, tenaga atau pikiran untuk masyarakat yang terkenah musibah banjir, longsor, tsunami dan lain-lain, menginfaqkan untuk pembangunan pesanteren, pembangunan masjid, pembangunan madrasah dan lain sebagainya yang nantinya berguna untuk kehidupan sosial. Dengan demikian dapat disimpulkan aktivitas kegiatan infaq yaitu pelaksanaan infaq yang dilakukan dengan rutin guna tercapainya tujuan tertentu dengan cara mengeluarkan harta yang dimiliki 
untuk kepentingan banyak orang (sosial) maupun kepentingan agama Islam (di jalan Allah). Selain itu manusia menyadari bahwa disetiap harta yang dimilikinya terdapak hak orang lain, dan itu wajib untuk dikeluarkan.

Kegiatan infaq yaitu rutinitias pelaksanaan infaq yang dilakukan secara terus menerus merupakan kegiatan unggulan dalam islam. Pengeluaran infaq disesuaikan dengan kadar dan kemampuan harta yang kita miliki serta semata-mata mengharap ridha Allah SWT. Selain itu mengharapkan kebaikan hidup di dunia maupun di akhirat hanya kepada Allah SWT, karena setiap yang kita infaqkan dengan ridha dan iklas baik itu infaq pikiran, tenaga maupun harta itu akan menjadi amal jariyah di akhirat kelak.

Dalam kegiatan infaq ditanamkan aspek kepekaan terhadap orang lain, peduli sosial terutama pada orang yang membutuhkan. Kegiatan infaq ini dalam implementasinya dikoordinir oleh pihak DKM Darul Ilmi SMAN 1 Bojongsoang yaitu oleh Dadang, S.Pd selaku ketua DKM dan dibantu oleh guru-guru SMAN 1 Bojongsoang yang bertugas sebagai guru piket pada hari itu serta sebagian siswa. Kegiatan infaq ini merupakan kegiatan infaq harian yang dilaksanakan mulai dari hari seni sampai hari jum'at. Dana infaq yang telah terkumpul diserahkan kepada pengurus DKM (bendahara DKM). Dana yang terkumpul dialokasikan untuk siswa yang terkena musibah, siswa sakit, kematian baik dari siswa maupun wali siswa, sumbangan sosial berupa sembako bagi masyarakat yang terkena musibah dan tidak mampu (fakir miskin), dan kaum lemah.

Indikator kegitan infaq menurut Arina Manasikana (2011) yaitu dilakukan dengan ikhlas, ungkapan rasa syukur, membantu orang yang membutuhkan, melatih kepekaan sosial, dan mengeluarkan harta yang dimiliki karena dari harta yang kita miliki ada hak orang lain.

Secara bahasa, ikhlas bermakna bersih dari kotoran. Sedangkan secara istilah, ikhlas berarti niat mengharap ridha Allah semata dalam beramal sebagai wujud menjalankan ketaatan kepada Allah dalam kehidupan dalam semua aspek. Ikhlas memiliki kedudukan yang sangat penting dalam setiap amalan, baik amalan hati, lisan, maupun badan. Syukur adalah salah satu refleksi dari sikap tawakal. Syukur ialah sesuatu yang menunjukkan kebaikan dan penyebarannya. Sedangkan secara istilah, syukur ialah memberikan pujian kepada Allah Swt. dengan cara taat kepada-Nya, tunduk dan berserah diri hanya kepada Allah SWT. Tolong menolong dalam bahasa Arabnya adalah $\mathrm{Ta}^{\prime} a w u n$. Sedangkan menurut istilah, pengertian $\mathrm{Ta}^{\prime}$ awun adalah sifat tolong menolong di antara sesama manusia dalam hal kebaikan dan taqwa. Infaq bisa dikatakan juga sebagai sedekah yang bermakna memberikan atau membelanjakan sesuatu yang menjadi hak orang lain. Infaq merupakan sebuah ibadah yang sangat mulia dalam pandangan Islam. Infaq berarti mengeluarkan sebagian uang atau rezeki yang kita miliki kepada yang lebih membutuhkan.

M Syah (2017: 118) Dalam arti sederhana sikap yaitu kecenderungan mental atau pandangan. Menurut Bruno sikap (attitude) yaitu kecenderungan yang relatif menetap untuk bereaksi dengan cara baik maupun buruk terhadap orang atau barang tertentu. Kata sosial digunakan untuk menunjukan sifat dari makhluk yang bernama manusia. Sehingga munculah ungkapan bahwa manusia adalah makhluk sosial. Ungkapan ini berarti bahwa manusia harus hidup berkelompok atau bermasyarakat. Mereka tidak bisa hidup dengan baik kalau tidak hidup dalam kelompok atau masyarakat, dengan kata lain untuk hidup memadai manusia harus berhubungan dengan manusia lain. Suatu golongan sosial juga merupakan satu kesatuan manusia yang ditandai oleh suatu ciri tertentu. Beni (2018) menjelaskan bahkan sering kali ciri itu juga dikenakan kepada 
mereka oleh pihak luar kalangan mereka sendiri. Walaupun demikian suatu kesatuan manusia yang disebut golongan sosial itu mempunyai ikatan identitas sosial.

Dengan demikian sikap sosial sesuai dengan penjelasan di atas telah diutarakan bahwa sikap adalah kesadaran individu yang menentukan perbuatan yang nyata dalam kegiatan- kegiatan sosial, maka sikap sosial adalah kesadaran individu yang menentukan perbuatan yang nyata, yang berulang-ulang terhadap objek sosial. Menurut Rukminto Adi, sikap sosial adalah sikap yang diyakini (dianut) sekelompok orang terhadap suatu objek. Misalnya sikap positif terhadap umat islam terhadap kehadiran bank muamalah Indonesia, atau sikap positif umat Kristen terhadap hari raya paskah, dan sebagainya (Adi,1994: 179). Sikap sosial secara umum adalah hubungan antara manusia dengan manusia yang lain, saling kebergantungan dengan manusia yang lain dalam berbagai kehidupan masyarakat. Sedangkan pendapat lain mengatakan interaksi dikalangan manusia, interaksi adalah komunikasi dengan manusia lain, hubungan yang menimbulkan perasaan sosial yaitu perasaan yang mengikatkan individu dengan sesama manusia, perasaan hidup bermasyarakat seperti saling tolong menolong, saling memberi dan menerima, simpati dan antipati, rasa setia kawan, dan sebagainya.

Manusia tidak dilahirkan dengan sikap pandangan atau sikap tertentu, tetapi sikap tersebut dibentuk sepanjang perkembangannya. Peran sikap dalam kehidupan manusia berperan besar, sebab apabila telah dibentuk pada diri manusia, maka sikap itu akan turut menentukan tinfkah lakunya terhadap objek-objek sikapnya. Adanya sikap menyebabkan bahwa manusia akan bertindak secara khas terhadap objeknya. Sikap dapat dibedakan menjadi sikap sosial dan sikap individual (Gerungan, 2010:161).

Sikap positif adalah sikap yang menunjukkan atau memperlihatkan, menerima, mengakui, menyetujui, serta melaksanakan normanorma yang berlaku dimana individu itu berada. Sedangkan sikap negatif: sikap yang menunjukkan atau memperlihatkan penolakan atau tidak menyetujui terhadap norma-norma yang berlaku dimana individu itu berada. (Smanpala, 2013).

Adapun ciri sikap itu adalah sikap bukan dibawa orang sejak ia dilahirkan, melainkan dibentuk atau dipelajarinya sepanjang perkembangan orang itu dalam hubungan dengan objeknya, sikap itu dapat berubah-ubah, karena itu sikap dapat dipelajari orang atau sebaliknya, sikap-sikap itu dapat dipelajari, karena itu sikap dapat berubah pada orang-orang bila terdapat keadaan- keadaan dan syaratsyarat tertentu yang mempermudah berubahnya sikap pada orang itu, sikap itu tidak berdiri sendiri, sikap itu dapat berkenaan dengan satu objek saja, tetapi juga berkenaan dengan sederetan objek-objek yang serupa dan sikap mempunyai segi-segi motivasi dan segisegi perasaan.

Fungsi sikap menurut Fattah (2012:66-67), terdiri dari empat fungsi sikap. Empat fungsi sikap itu adalah fungsi penyesuaian diri, fungsi pertahanan diri, fungsi ekspresi nilai, dan fungsi pengetahuan.

Indikator sikap sosial menurut Tim Penyusun Bahan Pembinaan Bidang PAIS (2016: 29-31), yaitu kasih sayang pada sesama, menjaga kebersihan diri, menjaga kebersihan lingkungan, disiplin dan peduli. Indikator adalah acuan yang digunakan sebagai dasar untuk melihat perubahan pada objek yang diteliti.

Pengertian ihsan dari sisi kebahasaan, kata Ihsan berasal dari kata kerja (fi'il) Hasuna-Yahsunu-Hasanan, artinya baik. Taharah berasal dari kata bahasa Arab yang berarti bersih atau bersuci. Sedangkan menurut istilah ialah suatu kegiatan bersuci dari najis dan hadats sehingga seseorang diperbolehkan untuk beribadah yang dituntut harus dalam keadaan suci. Kegiatan bersuci dari najis itu meliputi menyucikan badan, 
pakaian, tempat dan lingkungan yang menjadi tempat segala beribadah. Di samping masalah kebersihan diri, Islam juga sangat memperhatikan kebersihan lingkungan yang ada di sekitar kita, karena sebagai agama yang menjadi rahmat bagi sekalian alam. Disiplin mempunyai arti ketaatan dan kepatuhan pada aturan, tata tertib dan lain sebagainya. (Tim Penyusun Kamus Pusat Pembinaan dan Pengembangan Bahasa,1997: 747). Menurut Tabrani Rusyan, disiplin adalah suatu sikap menghormati, menghargai, patuh dan taat kepada peraturan-peraturan yang berlaku, baik yang tertulis maupun tidak tertulis serta sanggup menjalankannya dan tidak mengelak untuk menerima sanksi-sanksinya bila ia melanggar tugas dan wewenang yang diberikan kepadanya. Kepedulian berasal dari kata peduli. Peduli adalah sikap dan tindakan yang selalu berupaya mencegah dan memperbaiki penyimpangan dan kerusakan (manusia, alam, dan tatanan).

\section{Pengaruh aktivitas siswa dalam kegiatan infaq terhadap sikap sosial}

Setelah penulis selesai melakukan penelitian serta mengolah data melalui beberapa tahap teknik statistika dari dua variabel yang diteliti yaitu antara aktivitas kegiatan infaq dan sikap sosial mereka, maka telah diketahui hasil dari aktivitas siswa dalam kegiatan infaq dan sikap sosial mereka, yaitu:

Aktivitas kegiatan infaq dan sikap sosial merupakan pembahasan yang berbeda tetapi memiliki pengaruh dengan diadakannya aktivitas kegiatan infaq terhadap sikap sosial. (Samuel, 1982: 52), mengatakan bahwa aktivitas tidak hanya sekedar kegiatan, tetapi aktivitas dipandang sebagai usaha mencapai atau memenuhi kebutuhan. Aktivitas kegiatan infaq yaitu pelaksanaan infaq yang dilakukan dengan rutin guna tercapainya tujuan tertentu dengan cara mengeluarkan harta yang dimiliki untuk kepentingan banyak orang (sosial) maupun kepentingan agama Islam (di jalan Allah).

Aktivitas siswa dalam kegiatan infaq diperoleh dengan penyebaran angket berstruktur kepada 40 siswa sebagai sampel dalam penelitian ini. Angket ini memuat 15 pertanyaan yang dikembangkan dari indikator tanggapan siswa terhadap kegiatan infaq, yaitu: ikhlas, ungkapan rasa syukur, membantu orang yang membutuhkan, melatih kepekaan sosial dan mengeluarkan sebagian harta. Angket yang disebarkan kepada responden berbentuk pilihan soal. Jika soal favourable bagi resonden yang menjawab $\mathrm{SS}=5, \mathrm{~S}=4, \mathrm{R}=3, \mathrm{TS}=2$ dan $\mathrm{STS}=1$. Untuk soal unfavourable bagi resonden yang menjawab $S S=1, S=2, R=3, T S=4$ dan $S T S=5$. Adapun untuk mengetahui aktivitas siswa dalam kegiatan infaq siswa kelas XI.

Penentuan menghitung jumlah skor yang diperoleh dari tiap-tiap jawaban item dan mengelompokkannya sesuai dengan yang diperoleh, menghitung jumlah responden yang memilih alternatif jawaban setiap item dan menghitung skor rata-rata jawaban responden dari seluruh item dalam suatu variable berikut interpretasinya. Untuk menginterpretasi tinggi rendahnya jawaban responden tiap variable, mengacu pada tabel interpretasi pada tabel 1.

Tabel 1 Interpretasi

\begin{tabular}{c}
\hline Interpretasi \\
\hline $4,20-5,00=$ Sangat Tinggi \\
$3,40-4,19=$ Tinggi \\
$2,60-3,39=$ Cukup \\
$1,80-2,59=$ Rendah \\
$1,00-1,79=$ Sangat Rendah \\
\hline (Anas Sudjiono, 2009:85)
\end{tabular}

Untuk mengetahui keseluruhan dari keempat indikator tersebut dari aktivitas kegiatan infaq, maka dapat disimpulkan bahwa rata-rata aktivitas siswa dalam kegiatan 
infaq adalah sangat tinggi. Adapun pengujian normalitas variabel $\mathrm{X}$ berdasarkan hasil perhitungan menyatakan berdistribusi normal. Sedangkan untuk mengetahui keseluruhan dari kelima indikator tersebut dari sikap sosial mereka, maka dapat disimpulkan bahwa rata-rata sikap sosial mereka adalah tinggi. Adapun pengujian normalitas variabel $\mathrm{Y}$ berdasarkan hasil perhitungan menyatakan berdistribusi tidak normal.

Untuk mengetahui hubungan antara Variabel $X$ (aktivitas siswa alam kegiatan infaq) dengan Variabel Y (sikap sosial mereka), ialah dengan menguji kedua variabel tersebut dengan menggunakan langkah-langkah yang harus ditempuh adalah menggunakan rumus: persamaan regresi linier, linieritas regresi, koefisien korelasi, signifikasi korelasi dan besarnya pengaruh Variabel $\mathrm{X}$ terhadap Variabel Y. Secara sistematis hasil perhitungan pada analisis ini diperoleh rincian jawaban sebagai berikut:

\section{Persamaan Regresi Linier}

Dari hasil perhitungan persamaan regresi linier sebagaimana terlampir dalam lampiran, diperoleh harga sebesar $Y=56,467+0,094 x$. Dengan demikian persamaan regresi antara pengaruh aktivitas siswa dalam kegiatan infaq terhadap sikap sosial mereka ialah $Y=56,467+0,094 x$. Dengan demikian, aktivitas siswa dalam kegiatan infaq 56,467 akan meningkatkan sikap sosial mereka sebesar 0,094.

\section{Linieritas Regresi}

Beradasarkan perhitungan sebagaimana terlampir diperoleh hasil bahwa $F_{\text {hitung }} 12,652$ dan $F_{\text {tabel }} 2,13$. Hasil tersebut membuktikan $F_{\text {hitung }}>F_{\text {tabel }}$. Dengan dmikian dapat disimpulkan bahwa aktivitas siswa dalam kegiatan infaq dengan sikap sosial mereka sebagai variabel yang beregresi tidak linier. Untuk lebih jelasnya tentang uji linieritas regresi dapat dilihat pada lampiran.

\section{Koefisien Korelasi}

Untuk menentukan koefisien korelasi, formulasi rumus yang digunakan kolerasi Rank dari Spearman, dikarenakan salah satu variabel tidak berdistribusi normal dan regresi tidak linier. Maka hasil perhitungan antara aktivitas siswa dalam kegiatan infaq dengan sikap sosial mereka adalah 0,11 yang artinya koefisien korelasi antara Variabel $X$ dab Variabel $Y$ tergolong sangat rendah, karena terdapat pada interval 0,00 - 0,20 yang berarti termasuk kategori korelasi sangat rendah. Maka korelasi ini menyatakan bahwa pengaruh aktivitas siswa dalam kegiatan infaq terhadap sikap sosial mereka terdapat pada korelasi yang sangat rendah.

\section{Signifikasi Korelasi}

Berdasarkan perhitungan sebagaimana terlampir pada lampiran diperoleh harga $t_{\text {hitung }}$ sebesar 0,67 , dan $t_{\text {tabel }}$ pada taraf kepercayaan $5 \%(0,31)$ dan derajat kebebasan $(\mathrm{dk}=38)$. Hasil di atas membuktikan bahwa $t_{\text {hitung }}$ sebesar 0,67 , dan $t_{\text {tabel }}$ sebesar 0,31 . Hal ini berarti hipotesis alternatif (Ha) yang diajukan diterima, artinya terdapat pengaruh yang signifikan antara aktivitas siswa dalam kegiatan infaq terhadap sikap sosial mereka.

\section{Besarnya Pengaruh Variabel $X$ terhadap Variabel $Y$}

Berdasarkan perhitungan kedua data di atas, dapat disimpulkan bahwa Variabel X (aktivitas siswa dalam kegiatan infaq) mempunyai pengaruh sebesar 1,21\% terhadap Variabel Y (sikap sosial mereka). Dengan demikian selain faktor aktivitas siswa dalam kegiatan infaq yang telah disebutkan, masih banyak faktor-faktor lain yang mempengaruhi tinggi rendahnya sikap sosial mereka yang diperkirakan sebesar 98,79\%. Karena koefisien yang diperoleh 
arahnya tinggi, maka; "Semakin tinggi antusiasme siswa terhadap aktivitas kegiatan infaq, semakin tinggi pula sikap sosial siswa tersebut. Sebaliknya jika semakin rendah antusiasme siswa terhadap aktivitas siswa dalam kegiatan infaq, maka akan semakin rendah pula sikap sosial siswa tersebut".

\section{SIMPULAN}

Berdasarkan hasil penelitian pengaruh aktivitas siswa dalam kegitan infaq terhadap sikap sosial mereka, dapat ditarik simpulan bahwa, aktivitas siswa dalam kegiatan infaq menunjukkan kategori sangat tinggi. Hal ini didasarkan atas hasil pengisian angket oleh 40 responden yang menunjukkan nilai rata-rata sebesar 4,27. Menurut ukuran kualifikasinya angka tersebut termasuk kategori sangat tinggi karena berada pada interval 4,20 - 5,00. Sikap sosial menunjukkan kategori tinggi. Hal ini didasarkan atas hasil pengisian angket oleh 40 responden yang menunjukkan nilai rata-rata sebesar 4,16. Menurut ukuran kualifikasinya angka tersebut termasuk kategori tinggi karena berada pada interval 3,40 - 4,19. Pengaruh antara aktivitas siswa dalam pelaksanaan infaq terhadap sikap sosial mereka termasuk kategori sangat rendah. Dalam perhitungan koefisien korelasi tersebut diperoleh angka koefisien korelasi sebesar 0,11 angka korelasi ternyata signifikan $5 \%$ yang diajukan oleh nilai $t_{\text {hitung }}$ sebesar 0,67 , dan $t_{\text {tabel }}$ sebesar 0,31 . Hal ini berarti terdapat pengaruh yang signifikan antara Variabel $X$ dan Variabel Y. Ini juga menunjukkan bahwa hipotesis nol $(\mathrm{H} 0)$ ditolak dan hipotesis alternatif $(\mathrm{Ha})$ diterima. Angka koefisien korelasi 0,11 termasuk kategori sangat rendah karena berada pada interval 0,00 - 0,20. Sementara itu derajat pengatuh Variabel $X$ terhadap Variabel Y diketahui 1,21\% dan masih terdapat 98,79\% lagi faktor lain yang dapat mempengaruhi sikap sosial mereka yang perlu diteliti lebih lanjut.

\section{REFERENSI}

Adi, Isbandi Rukminto. (1994). Psikologi Pekerjaan Sosial, dan Ilmu Kesejahteraan Sosial, Jakarta:PT Raja Grafindo Persada.

Dapertemen Pendidikan dan Kebudayaan. (2004). Kamus Besar Bahasa Indonesia, Jakarta: Balai Pustaka

Faizal bin Ali Al-Ba'dani. (2009). 1001 Manfaat Nyata Sedekah,

Gerungan. (2010). Psikilogi Sosial, Bandung: PT Refika Aditama.

Muhibbin, Syah. (2017). Psikologi Pendidikan dengan Pendekatan Baru, Bandung: PT Remaja Rosdakarya

Musfirotun. (2013). Hubungan Keaktifan Mengikuti Kegiatan Pengajian Malam Jum'at Dengan Sikap Sosial Ibu Rumah Tangga Di Karangrejo Rt 003 Rw 003 Kelurahan Kecandran Kecamatan Sidomukti Kota Salatiga Tahun 2013 (Skripsi Sarjana), Sekolah Tinggi Agama Negeri, Salatiga.

Nursyamsudin. (2009). Fiqih, Jakarta.

Sudijono, Anas. (2008) Pengantar Statistika Pendidikan. Jakarta: Raja Grafindo Persada.

Siswanto, Wahyudi. 2010. Membentuk Kecerdasan Spiritual Anak. Jakarta: Amzah,

Terj. Ibnu Muslih dan Ade Macnun. Klaten: Inas Media. 
Smanpala. (2013). Sikap Positif dan Sikap Negatif, PT Keren Sekali. Diunduh pada 18 Februari 2019 dari http://budipekerti12.blogspot.com/2013/11/bab-4-sikappositif-dan-negatif.html

Soeltoe, Samuel. (1982). Psikologi Pendidikan II, Jakarta: FEUI

Tim penyusun bidang pendidikan agama islam, (2016). Panduan Praktis Penilaian Kurikulum 2013 Pendidikan Agama Islam dan Budi Pekerti pada Sekolah, (Bandung: Kemenag Jabar, 2016).

Tim Penyusun Kamus Pusat Pembinaan dan Pengembangan Bahasa. (1997). Kamus Besar Indonesia, Jakarta: Balai Pustaka

Eko Suswanto, “Analisis Produktivitas Pengelolaan Zakat Dari Sistem Bagi Hasil (Studi Kritis Bank Muamalat Cabang Kota Jayapura) 3-2", PALITA: Journal of SocialReligion Research (Oktober 2018): 141- 164

Beni Putra Hanafi "Pemberdayaan Masyarakat Melalui PKPU 2-2", Jurnal Al-Fuad (JuliDesember 2018): 232 